\title{
İki Portre Üzerine Yeni Bir Değerlendirme
}

\section{Araș. Gör. Yaşar Arlı ${ }^{1^{*}}$}

Geliş tarihi: 05.09.2019

Kabul tarihi: 16.09.2019

\section{Atıf bilgisi:}

IBAD Sosyal Bilimler Dergisi

Sayı: Özel Sayı Sayfa: 274-281

Yıl: 2019

This article was checked by Turnitin. Similarity Index $17 \%$.

${ }^{1}$ Akdeniz Üniversitesi, Türkiye, yasararli@akdeniz.edu.tr

ORCID ID 0000-0001-7799-6764

\begin{abstract}
ÖZ
Uluslararası portre araştırmacılığı alanında karşımıza çıkan en önemli husus bir portrenin resmi mi yoksa özel mi olduğu sorusudur. Bu soru aynı zamanda ele alınan portrenin hangi imparator veya imparatoriçeye ait olduğunu ya da hangi imparator veya imparatoriçeden esinlenerek ortaya konduğu sorularının cevaplarını da bizlere sunmaktadır. Böylelikle bu önemli husus, ele aldığımız eserin tanım ve tarihlendirilmesinde bizlere yol gösteren önemli bir faktördür. Uluslararası portre araştırmacılığı kriterlerine bağlı kalarak ele aldığım bu yazımda, 1949 ve 1971 yıllarında Buschor tarafindan ele alınan erkek başı aynı zamanda 1966 yılında İnanRosenbaum tarafindan da ele alınmış olup ortaya iki farklı tanım ve tarihlendirme çıkmışıı. Kadın başı ise 1974 yılında İnan ve 1979 yılında da İnan-Rosenbaum tarafindan ele alınmış olup daha sonraları ise Fejfer ve Güven'de dahil olmak üzere pek çok araştırmacı tarafindan incelenmiş ve her bir araştırmacı tarafindan da farklı bir tanım ve tarihlendirme yapılmıștır. Bu yüzden yukarıda belirttiğim sorulara cevap aramak kaygısıyla ele aldığım bu çalışmamda, tanım ve tarihlendirme konusunda ayrılıkların yaşandığı erkek başı ile kadın başı hakkında yeni bir yorum getirmeye çalışacağım.
\end{abstract}

Anahtar Kelimeler: portre, baş, Vespasian, Traian dönemi.

\footnotetext{
* Sorumlu yazar
} 


\title{
A New Assessment on Two Portraits
}

\author{
Res. Assist. Yaşar Arlı ${ }^{{ }^{*}}$
}

First received: 05.09.2019 Accepted: 16.09.2019

\section{Citation:}

IBAD Journal of Social Sciences Issue: Special Issue Pages: 274-281 Year: 2019

This article was checked by Turnitin. Similarity Index $17 \%$.

\footnotetext{
${ }^{1}$ Akdeniz University, Turkey, vasararli@akdeniz.edu.tr

ORCID ID 0000-0001-7799-6764
}

* Corresponding Author

\begin{abstract}
The most important issue in the field of international portrait research is whether a portrait is official or private. This question also presents the answers to the questions of which emperor or empress the portrait belongs to or which emperor or empress was inspired by. Thus, this important issue is an important factor guiding us in the definition and dating of the work we are dealing with. In this article, which I dealt with according to the criteria of international portrait research, the male head which dealt with by Buschor in 1949 and 1971 and was also handled by Inan Rosenbaum in 1966, has emerged two different definitions and dating dates. The female head has been studied by Inan in 1974 and Inan-Rosenbaum in 1979 and later, it has been examined by many researchers, including Fejfer and Güven and a different definition and dating has been made by each researcher. Therefore, in this paper prepared with the concern of finding answers to the questions mentioned above, I will try to make a new interpretation about male and female heads on which there are disagreements about definition and dating.
\end{abstract}

Keywords: Portrait, head, Vespasianus, Traianus period. 


\section{INTRODUCTION}

There are some disaggreements about names and dating of two pieces examined by many researchers until today. These two pieces which I have scrutinised within the frame of my progressing doctoral study have been reinterpreted with new information and documents. The two important studies published by J. Inan and E. A. Rosenbaum between 1966-1979 are quite important in terms of evaluating portrait art of Anatolian Roman Period in a holistic manner. Because these two important studies contain a quite wide geography and a long chronology, they could not examine Anatolian portrait art in details. Except these two studies, Anatolian portrait art has been examined by individual expressions, this constituted a problem in terms of the development of portrait art in Anatolia. Anatolian originated portraits which have not been examined in a holistic approach have been the subject of different expressions many times. Therefore, pieces of Pergamon and Perge have been reexamined for justified reasons.

\section{Male Head (Plate I)}

Bergama Museum (Inv. No. 1916)

Pergamon.

H. H. 34,2 cm. H. W. $28 \mathrm{~cm}$.

Medium grained crystalline white marble.

Vespasianus Period (AD 69-79)

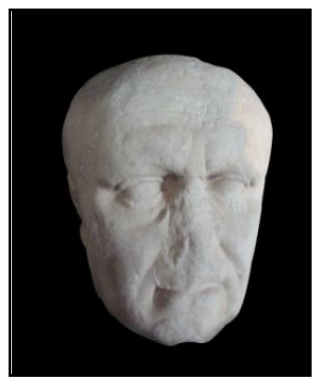

Resources: Winter 1908, 230 Figure 278; Buschor 1949, 50, 55 Figure 45; İnan-Rosenbaum 1966, 67 Plate 16 Figure 2, 3; Buschor 1971 Figure 61.

The head is broken and missing from the beginning of the neck. There is a big tear-off at the top of the head. The nose is completely broken. There is seen sprodically abrasions and bruises on the face. There are small lost parts on the forehead, ear, lips and chin.

Considering physiognomic features of the person described, the piece must belong to an old male. The upper part of the head is roughly processed. Except hair combed from temporals and rear part of the head to the nape, there is no hair at the front part. There are wrinkles on the face as a sign of old age. The wrinkles given with parallel lines on wide and bare forehead have been processed with deep lines on the face. Skin saggings downwards from both sides of the nose wings are seen. The saggy face skin is also another sign of elderliness. He has a flat and strong skull. The eyebrows are processed in the form of a bow. The eyes are deeply placed and the eyelids are swollen. Although the nose is broken, it is big as understood from the part which is left. The ears have been processed proper to facial anatomy, and they are natural. Inspite of wide facial structure, the mouth is small and closed. There are small pits on both sides of the mouth. The chin is round and fat.

The head of Pergamon introduced to the scientific world by many researchers has been interpreted differently by each researcher. For instance, F. Winter has interpreted Pergamon piece as a special portrait dated to Roman imperial period (Winter, 1908, p. 230). After F. Winter, E. Buschor has dated the head with inventory number 1916 to 1st century BC in his publications in both 1949 and 1971 (Buschor, 1949, pp. 50, 55: figure 45; Buschor, 1971, figure 61). Contrary to the opinions of both researchers, J. Inan and E. A. Rosenbaum have interpreted Pergamon piece as a Vespasianus portrait with his own physiognomic features, not an ordinary person and dated to Flavian period (Inan and Rosenbaum, 1966, p. 67, plate 16, figure 2, 3).

The physiognomic features of Pergamon head are repetition of main type portraits of Vespasianus as an old man (Fittschen and Zanker, 1985, p. 33, plate 27, 2, figure 27). When we compare Pergamon piece with Vespasianus portrait in Ny Carlsberg Glyptotek Museum in Copenhagen (De Puma, 1988, p. 6: figure 1; Levick, 1999, plate 3, figure 5), it supports this view. In both pieces, the physiognomic features such as baldness of the person depicted based on elderliness, wrinkles on the forehead and face, saggy face skin, flattened and strong skull, large face and forehead, deeply placed eyes, small motuh and collapsed surrounding of the mouth, fat and round chin show similarity. The coins with depiction of Vespasianus portraits (Förschner, 1959/60, plate 1) also verify this this similarity. As a result of this 
similarities, the male head interpreted as Vespasianus by us has to be dated to second half of his emperorship (De Puma, 1988, p. 6, plate 1).

\section{Female Head (Plate II)}

Antalya Archaeology Museum (Inv. No 3281)

Perge.

H. H $31 \mathrm{~cm}, \mathrm{H} . \mathrm{W} 20 \mathrm{~cm}$.

Fine crystalline white marble.

1.Traianus Period (AD 98-117)

2. Severan Period (AD 193-211)

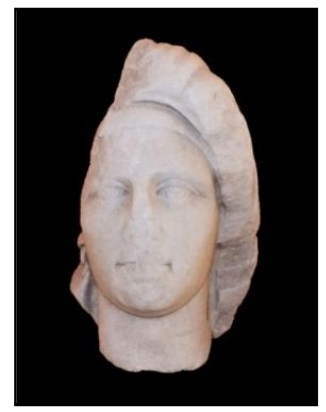

Resources: Inan 1974, 661 Plate 218; Inan-Rosenbaum 1979, 256 Plate 167; Fitschen 1984, 207 No. 234:1-2; Schmidt-Colinet 1991, 443; Meischner 2001, 181; Fejfer 2008, 363 Fig. 304; Güven 2014, 207, 208, 209 Plate 78.

The head is broken and missing from the beginning of the neck. The right side of headscarf and right side of the forehead are torn off. There is a damage on the face of the piece. The nose is broken, right eye is eroded. The mouth and chin are slightly broken off.

Considering physiognomic features of the head, the piece must belong to an adult woman. Due to thick headscarf on the head of the piece, it is thought that it belongs to a clothed portrait statue. There is a high mass of hair combed backwards in the front of the forehead. The end part of hair tresses flowing downwards from thick headscarf is wavy. Except the high mass of hair on the front of the forehead, all hair and ears are under the thick headscarf. There is a wide band on the forehead just under the headscarf. The lower part of high forehead is slightly swollen. Despite abrasion, the eyebrows are thin and bow-shaped. The pupil and the iris have been processed. The pupil and the iris are in the form of circular rings placed into each other. Some part of the pupil and the iris are under the upper eyelid. The upper eyelids are thicker tha the lower ones. The eyes are opened, the eyelids stretch towards the eye flares. It is thought that the broken nose is flat from the part which is left. There are superficial lines coming downwards from the nose wings. The mouth is closed, the lips are thin. There are small concavities seen at the edges of closed mouth. The chin is fat. The dewlap under the chin is apparent. The face is oval, the cheeks are plump.

There are many views and suggestions about the female head interpreted by many researchers until today. For instance, Perge head which was discussed by J. Inan in 1974 (Inan, 1974, p. 661) was reexamined once again by J. Inan and E. A. Rosenbaum (Inan and Rosenbaum, 1979, p. 234) in 1979 and dated to the Tetrarchy period in both publications. In 2008, J. Fejfer dated Perge head to Severan period contrary to these dates (Fejfer, 2008, p. 363). In 2014, B. A. Güven emphasized in her doctoral thesis study that Perge head was processed twice (Güven, 2014, p. 209). In her study, while B. A. Güven dated the first craftsmanship of Perge portrait to Traianus period, she suggested a wide range of time such as $280-\mathrm{V}^{\text {th }}$ century AD for the second craftsmanship (Güven, 2014, p. 209).

The fact that wreath-like hair mass on Perge portrait has been transformed into a high hair mass under the thick veil by being trimmed and hair band on the forehead has been shaped by being trimmed hair tresses enclosing the forehead such as a facile crown from ear to ear are indicators of second craftsmanship of the portrait. The fact that hair band on the forehead has no functionality and the ear under the veil has not been processed supports this view expressed by also B. A. Güven. When examined the hairdressing fashion on Perge head, the first craftsmanship has to be dated to Traianus period; because when we compare Perge piece with portraits of Traianus period, it is thought that high hair mass on the forehead is similar to a wreath-like hair mass placed on the forehead before being trimmed (Herrmann, Jr., 1991, p. 38, figure 4a,b) or double-layer hair mass enclosing the forehead such as a facile crown from ear to ear (West, 1941, plate 19, figure 70, 70a, 71, 72). When we compare Perge head with the portrait of Ulpia Marciana exhibited in Ostia (Wegner, 1956, plate 35, figure 75, 75a-b ) as a result of these similarities, similarity of slight swollen forehead, stretching eyelids to the eye flares, plump cheeks, 
facile channels coming downwards from nose wings, thin lip and fat chin supports the idea that the first craftsmanship belongs to Traianus period meanwhile. Also, the wavy processing of hair tresses coming downwards from the thich veil and processing of pupil and the iris are quite different from portrait style of Traianus period. As J. Fejfer suggested, who has not mentioned about the second craftsmanship of the portrait, when we compare Perge head with portrait of Iulia Domna in Capitoline Museum (Fittschen and Zanker, 1983, p. 29, plate 39), wavy hair coming downwards from the thick veil and processing of circular rings-shaped pupil placed into each other are similar. The second craftsmanship of Perge portrait rendered as a result of these similarities also has to be dated to Severan period.

\section{CONCLUSION}

Pergamon head reinterpreted by us reflects genuine physiognomic features of elderly Vespasianus who came to the throne in $69 \mathrm{AD}$ rather than veristic expression on pieces of 1st century $\mathrm{BC}$. For Antalya piece which has second craftsmanship, while the first craftsmanship is being dated to Traianus period, the second craftsmanship is dated to Septimus Severus period with its justifications.

Bilgilendirme / Acknowledgement: This article has been compiled from my doctoral thesis study entitled as "Portrait Art of Flavian and Traianus Periods in Anatolia" which is being conducted and continued under consultancy of Prof. Dr. Havva Işık. In 34 museums, scientific research has been conducted under my thesis title. Funding for scientific researches has been provided by Akdeniz University FMTP Funding Unit, Akdeniz University Scientific Research Coordination Unit (SRP) and Koç University Suna \& Inan Kıraç Research Center for Mediterranean Civilizations (AKMED), I thank to each unit for their supports.

\section{REFERENCES}

Busschor, E. (1949). Das hellenistische bildnis. Münih: Verlag.

Buschor, E. (1971). Das hellenistische bildnis. Münih: Verlag.

Carradice, I. (1998). Towards a new introduction to the flavian coinage. Bulletin of the institute of classical studies. Supplement, No: 7, MODUS. New Jersey: Wiley.

De Puma, R. D. (1988). Roman potraits. Iowa City: The University of Iowa Museum of Art.

Fejfer, J. (1998). Roman portraits in context. Berlin-Newyork: Walter der Grayter.

Fittschen, K. ve Zanker P. (1983). Katalog der römischen porträts in den capitolinischen museen und der anderen kommunalen sammlungen der stadt rom-text. Batı Almanya: Philipp von Zabern.

Fittschen, K. ve Zanker P. (1983). Katalog der römischen porträts in den capitolinischen museen und der anderen kommunalen sammlungen der stadt rom-tafeln. Batı Almanya: Philipp von Zabern.

Förscher, G. (1959/60). Das porträt vespasians auf römischen münzen. Berlin: Sonderdruck.

Güven, B. A. (2014). Pamphylia bölgesi roma dönemi portreciliği. Yayımlanmamış doktora tezi, İstanbul Üniversitesi, İstanbul.

Herrmann, Jr. J. J. (1991). Rearranged hair: a portrait of a roman in boston and some recarved portraits of earlier imperial times. Journal of the Museum of Fine Arts, 3, 34-50.

İnan, J. (1966). Roman and early Byzantine portrait sculpture in Asia Minor. Londra: Oxford University Press.

İnan, J. (1974). Neu porträtstatuen aus perge. Mansel'e Armağan II. Ankara: TTK Basımevi.

İnan, J. ve Rosenbaum, E. A. (1979). Römische und frühbyzantinische porträplastik aus der türkeitafeln. Münih: Verlag. 
İnan, J. ve Rosenbaum, E. A. (1979). Römische und frühbyzantinische porträplastik aus der türkei-text. Münih: Verlag.

Levick, B. (1999). Vespasian. Newyork: Routledge.

Meischner, J. (2001). Bildnisse de spätantike 193-500: problemfelder die privatportrats. Berlin: Edition BNB.

Schmidt-Colinet, A. (1991). Eine severische priesterin aus syrien in perge. Istanbuler Mitteilungen, 41, 439-445.

Wegner, M. (1966). Das römische herrscherbild: die flavier (vespasian.titus.domitian.nerva.iulia titi. Domitilla.domitia). Berlin: Verlag Gebr.

West, R. (1933). Römische porträt-plastik. Münih: F. Bruckmann K. G.

Winter, F. (1908). Altertümer von pergamon, VII.2: Die skulpturen mit ausnahme der alterreliefs. Berlin: Verlag von Georg Reimer. 
PLATE I
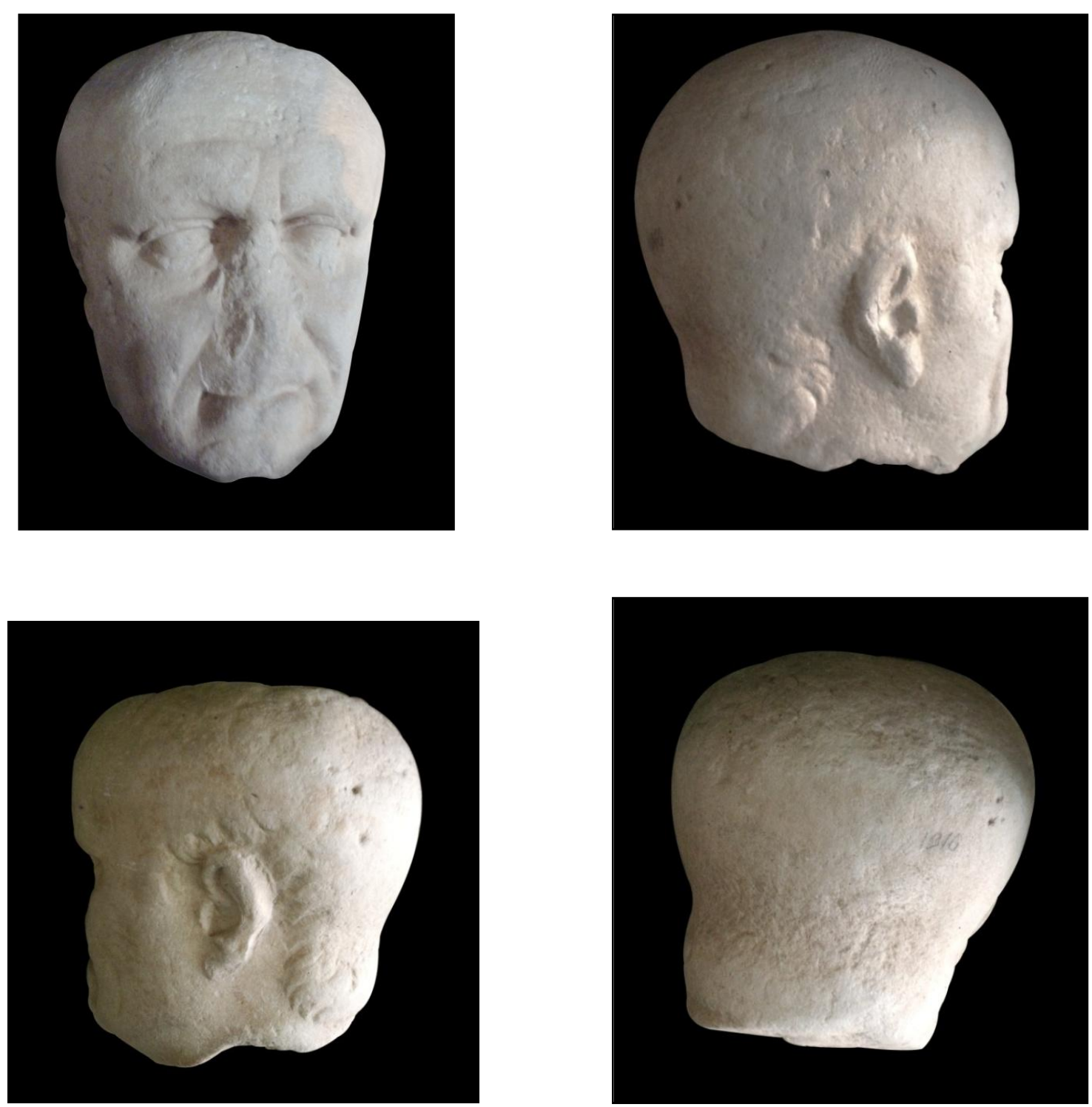

Plate I. Bergama Museum, Vespasianus Portrait. (Photo: Yaşar ARLI, 2017). 
PLATE II
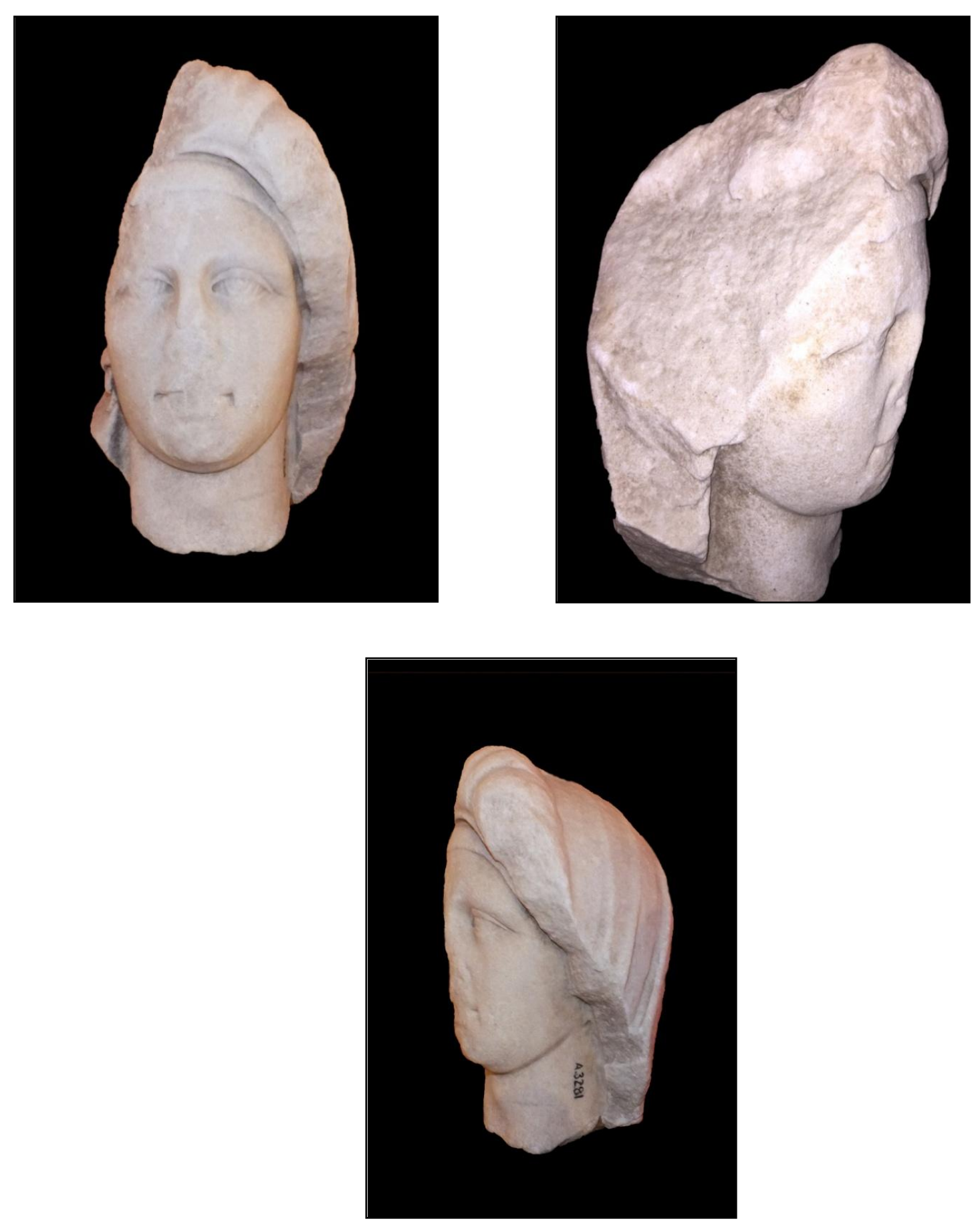

Plate II. Antalya Archaeology Museum, Private Women Portrait. Photo: Yaşar ARLI, 2017). 